\title{
瞳孔対光反射の分光感度に対する 視物質メラノプシンを含む網膜神経節細胞の寄与
}

\author{
正会員 高 橋 良 香 (千葉大学) 非会員 勝 浦 哲 夫（千葉大学） \\ 非会員 岩 永 光 - (千葉大学) 非会員 下 村 義 弘 (千葉大学)
}

\section{Contribution of Intrinsically Photosensitive Retinal Ganglion Cells on Action Spectrum for Pupillary Light Reflex}

\begin{abstract}
Member Yoshika Takahashi (Chiba University), Non Member Tetsuo Katsuura (Chiba University)
Non Member Koichi Iwanaga (Chiba University) and Non Member Yoshihiro Shimomura (Chiba University)
\end{abstract}

KEYWORDS : pupil, action spectrum, melanopsin, lens, aging, template

\section{1. はじめに}

錐体でも杆体でもない光受容器が発見された 1). それは視物質メ ラノプシンを含む網膜神経節細胞（ipRGC）であり，その神経出力 は生体リズムの中枢である視交叉上核や瞳孔対光反射に関係する 視蓋前域オリーブ核, 外側膝状体の一部の層へ投射している 2). 生 体リズムおよび睲孔対光反射に代表される非視覚的作用には錐体 や杆体などの既知の光受容器とipRGC が共に関与していて, これ ら 3 種類の光受容器のすべてを働かなくさせると生体リズムや瞳孔 対光反射への光入力がなくなることが報告されている ${ }^{3)}$.このこと から, 生体リズムや瞳孔対光反射への光入力は錐体, 杆体, ipRGC に限られることが示されている.

瞳孔対光反射に ipRGC が関与することはマウス 3)4), マカクザル 5)，ヒト5)6)を対象とした実験から報告されており，高放射量曝露時 の瞳孔対光反射に ipRGC が関与することがマウスを使った実験か ら示唆されている 344)。そこで, 本研究ではヒトを対象に, 瞳孔対 光反射の分光感度を調べ, ipRGC が関与すると考えられる分光感 度特性が現れるか調べることを研究目的とした。

\section{2. 実験方法}

\section{1 研究デザイン}

瞳孔対光反射の分光感度は低放射量曝露時には杆体 7)で調節さ れ, 高放射量曝露時にはipRGCで調節されるという仮説を立てた。 この仮説を確かめるため, プルキンエ現象（図1）の概念を利用し, 中心波長が $457 \mathrm{~nm}$ と $539 \mathrm{~nm}$ の 2 種類の単色光による放射量と瞳 孔径の関係を調べた. 分光感度変化があった時は, 2 つの単色光に よる放射量と瞳孔径の関係を表す近似曲線が交差すると考えた.

図 1 の杆体の分光感度は $V^{\prime}(\lambda)$ から作成し, ipRGC の分光感度は 視物質テンプレート 8) と水晶体の分光吸収特性 9)から作成した. ipRGC の視物質のピーク波長は $484 \mathrm{~nm}^{1)}$ とした。 プロットは 457 $\mathrm{nm}$ と $539 \mathrm{~nm}$ における杆体（○）と ipRGC（○）の感度である。

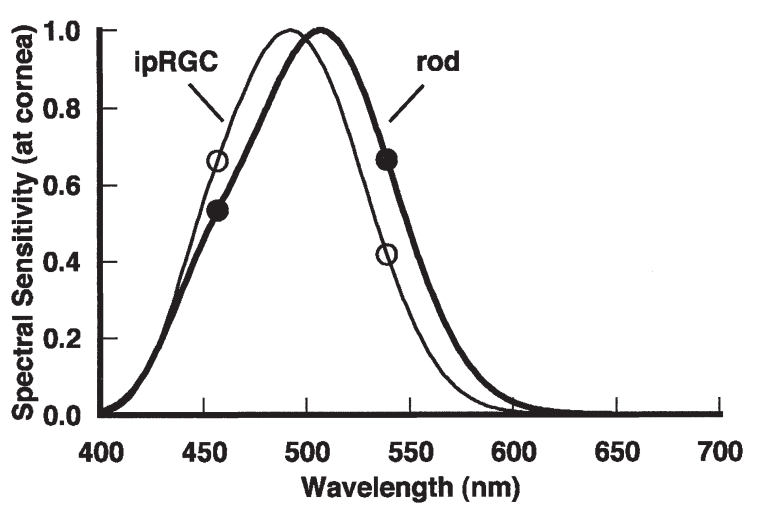

図 $1 i p R G C$ と杆体の分光感度

Fig.1 Spectral sensitivities of intrinsically photosensitive retinal ganglion cells (solid line), rod (bold line).

\section{2 被験者}

平均年齢 26 歳（22 33 歳）の男性被験者 4 名（被験者 $\mathrm{A}: 33$ 歳, 被験者 B : 25 歳, 被験者 $\mathrm{C}: 24$ 歳, 被験者 D : 22 歳が実験 に参加した。すべての被験者の色覚が正常であることを Farnsworth-Munsell 100 Hue TESTによって確認した.

\section{3 実験方法}

実験は午前中に実施した.被験者はまず, 30 秒間暗順応した後, 30 秒間の光曝露中, $250 \mathrm{~mm}$ 前方にある固視点を両眼で注視し た，その後， 30 秒間休䕀した．これを同一条件で 5 回繰り返した 後, 室内灯 (白熱電球) を点灯して, 2 分間休熄した.

光量は $457 \mathrm{~nm}$ 光が $0.0122 \sim 7.26 \mu \mathrm{W} / \mathrm{cm}^{2} \quad(0.0280 \sim 16.7 \times$ $10^{12}$ photons $\left./ \mathrm{cm}^{2} / \mathrm{s}\right), 539 \mathrm{~nm}$ 光が $0.0314 \sim 12.5 \mu \mathrm{W} / \mathrm{cm}^{2}(0.0853$ $\sim 33.9 \times 10^{12}$ photons $/ \mathrm{cm}^{2} / \mathrm{s}$ ) の範囲で, 各 10 段階の条件があつ た. 1 回の実験では 10 段階の条件を放射量の大きい 5 条件と小 さい 5 条件に分け，いずれかの条件が用いられた。 5 条件内の順 
番は大から小，小から大への放射量の変化が同数になるようにし た. 各測定条件の繰り返し数は被験者 A が 40 回, 他の 3 名が 20 回だった.

\section{4 実験装置}

$500 \mathrm{~W}$ のタングステンランプと狭帯域透過型干渉フィルタを組 み合わせることで単色光を作り出した (半值全幅 $11 \mathrm{~nm}$ の中心波長 $457 \mathrm{~nm}$ の光と半值全幅 $12 \mathrm{~nm}$ の中心波長 $539 \mathrm{~nm}$ の光). 単色光 は被験者の $250 \mathrm{~mm}$ 前方にある $20 \mathrm{deg}$ の円形開口部から曝露した. 開口部には乳白色アクリル板があり, 拡散光を被験者は観察した。 被験者の角膜位置における単色光の分光放射照度は分光放射照度 計 HSR-8100（マキ製作所）で計測した。

瞳孔径は赤外線 LED 付き瞳孔検出カメラを使った眼球運動計測 装置 EMR-8（ナックイメージテクノロジー）によって, 暗順応と 光曝露をしている間, 左目を $60 \mathrm{~Hz}$ のサンプリングレートで記録し た。瞳孔計測中, 被験者の頭部はあご台で固定した。

\section{5 分析方法}

瞳孔径の測定值には光曝露開始後 10〜20 秒の平均值を用いた. 放射量と瞳孔径の関係は(1)式の 4 パラメータロジスティック関数 を用いて分析した.

最大瞳孔径 $A_{1}$ は各被験者の暗所下における瞳孔径の実測值（被 験者 $\mathrm{A}: 6.17 \mathrm{~mm}$, 被験者 $\mathrm{B}: 7.02 \mathrm{~mm}$, 被験者 $\mathrm{C}: 7.06 \mathrm{~mm}$, 被 験者 D : $6.10 \mathrm{~mm}$ ）を用いた。最小瞳孔径 $A_{2}$ は $2 \mathrm{~mm}$ とした。

$$
Y=\frac{A_{1}-A_{2}}{1+\left(X / X_{50}\right)^{p}}+A_{2} \ldots \ldots \ldots \ldots
$$

$Y$ : 瞳孔径, $X$ : 放射照度, $A_{1}$ : 最大瞳孔径, $A_{2}$ : 最小睲孔径,

$X_{50}: A_{1}$ と $A_{2}$ の中間の反応を示した時の放射照度, $p: A_{1}$ と $A_{2}$ の間にある曲線部分の傾き

\section{3. 実験結果}

\section{1 分光感度変化の有無}

図 2 に 4 名の被験者の放射量に対する瞳孔径の実験結果を示 す。プロットは実験結果, 近似曲線は(1)式を使った実験結果の近 似曲線である.4名の被験者の寸べてで放射量が変化することで $457 \mathrm{~nm}$ 光と $539 \mathrm{~nm}$ 光の近似曲線が交差した.

\section{2 近似曲線の交点の放射量と測光量（年齢補正前）}

近似曲線の交点を分光感度特性が変化する放射量と仮定した。 $457 \mathrm{~nm}$ 光と $539 \mathrm{~nm}$ 光による近似曲線の交点は被験者 $\mathrm{A}$ が 35.0 $\mu \mathrm{W} / \mathrm{cm}^{2}$, 被験者 B が $2.26 \mu \mathrm{W} / \mathrm{cm}^{2}$, 被験者 $\mathrm{C}$ が $1.15 \mu \mathrm{W} / \mathrm{cm}^{2}$, 被験者 D が $4.68 \mu \mathrm{W} / \mathrm{cm}^{2}$ だった。平均值と $95 \%$ 信頼区間は対数 に変換して計算した。平均值は $4.54 \mu \mathrm{W} / \mathrm{cm}^{2}, 95 \%$ 信頼区間は $0.432 \mu \mathrm{W} / \mathrm{cm}^{2}, 47.7 \mu \mathrm{W} / \mathrm{cm}^{2}$ だった. 瞳孔対光反射の分光感度は 杆体の分光感度で調節される 7) と考えられているため, 暗所視照 度で表すと，平均值は 46.0 scotopic lx，95\%信頼区間は 4.38
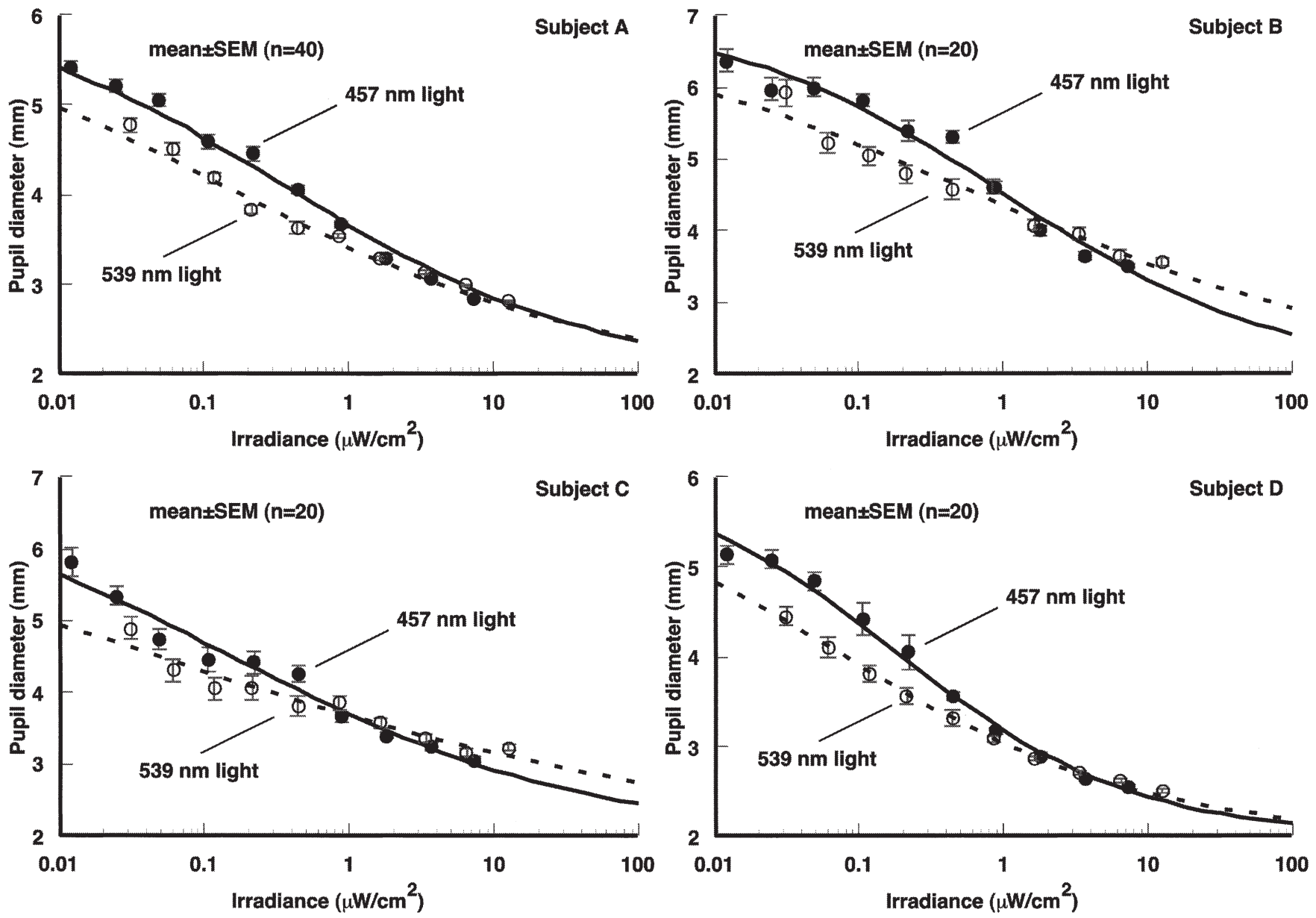

図 $2457 \mathrm{~nm}$ 光と $539 \mathrm{~nm}$ 光を用いた放射量に対する瞳孔径 (年齢補正前)

Fig.2 Mean pupil diameter \pm SEM as a function of irradiance using $457 \mathrm{~nm}$ light (solid line) and $539 \mathrm{~nm}$ light (broken line). 
scotopic lx, 483 scotopic lx だった.

\section{3 近似曲線の交点の放射量亡測光量 (年齢補正後)}

水晶体の分光透過率の加齢による変化の影響を取り除くため, 各 光条件の放射量を各被験者の年齢に応じた水晶体の分光透過率 10$)$ をかけて, 網膜位置における放射量に変換した，その後，被験者の 平均年齢 (26 歳) の水晶体の分光透過率 10)をもつ被験者の角膜位 置における放射量に変換して, 近似曲線の交点の放射量を求めた.

年齢補正後の近似曲線の交点は被験者 $\mathrm{A}$ が $4.49 \mu \mathrm{W} / \mathrm{cm}^{2}$, 被験者 $\mathrm{B}$ が $2.32 \mu \mathrm{W} / \mathrm{cm}^{2}$, 被験者 $\mathrm{C}$ が $1.21 \mu \mathrm{W} / \mathrm{cm}^{2}$, 被験者 D が 5.55 $\mu \mathrm{W} / \mathrm{cm}^{2}$ だった. 平均值と $95 \%$ 信頼区間は対数に変換して計算した. 平均值は $2.89 \mu \mathrm{W} / \mathrm{cm}^{2}, 95 \%$ 信頼区間は $0.963 \mu \mathrm{W} / \mathrm{cm}^{2}, 8.67$ $\mu \mathrm{W} / \mathrm{cm}^{2}$ だった。暗所視照度で表すと, 平均值は 29.3 scotopic lx, 95\%信頼区間は 9.76 scotopic lx, 87.8 scotopic lx だった。

\section{4 交点の前後の分光感度}

近似曲線の交点の前後で実験条件を $2 つ に$ 分け, 交点の前後で瞳 孔対光反射の分光感度を求めた. 2 種類の単色光から分光感度を求 める方法は Bronstein らの分光感度の推定方法 11)を用いた. 具体的 には， $A_{1}, A_{2}, p$ を共通にした(1)式で, $457 \mathrm{~nm}$ 光と $539 \mathrm{~nm}$ 光の 実験結果を表寸近似曲線を作成し, $457 \mathrm{~nm}$ 光, $539 \mathrm{~nm}$ 光の $X_{50}$ を求めた. 次に, 得られた $X_{50}$ を逆数にし, 正規化して $457 \mathrm{~nm}$ 光 と $539 \mathrm{~nm}$ 光の感度差を算出した. $457 \mathrm{~nm}$ と $539 \mathrm{~nm}$ の感度差が 実験結果と一致する視物質のピーク波長を視物質テンプレート8)か ら求めた。この方法により, 分析に用いた区間の瞳孔対光反射を調 節する視物質のピーク波長を推定した．また，分析に用いた各光条 件の放射量は被験者の年齢に応じた水晶体の分光透過率 10)をかけ, 網膜位置における放射量に変換したものを用いた.

交点より暗い時の瞳孔対光反射を調節する視物質のピーク波長 の推定值は被験者 $\mathrm{A}$ が $506 \mathrm{~nm}$, 被験者 B が $512 \mathrm{~nm}$, 被験者 $\mathrm{C}$ が $513 \mathrm{~nm}$, 被験者 D が $510 \mathrm{~nm}$ だった. 4 名の被験者の平均值は 510 $\mathrm{nm}$ だった。交点より明るい時の瞳孔対光反射を調節する視物質の ピーク波長の推定值は被験者 B が $478 \mathrm{~nm}$, 被験者 C が $481 \mathrm{~nm}$ だ った．被験者 $\mathrm{A} ， \mathrm{D}$ は分析に使用できる条件数が十分ではなかった ため, 分析できなかった. 2 名の被験者の平均值は $479 \mathrm{~nm}$ だった.

\section{4. 考察}

4 名の被験者のすべてで $457 \mathrm{~nm}$ 光と $539 \mathrm{~nm}$ 光による放射量と 瞳孔径の関係を表す近似曲線が交差したことから, 放射量が変化す ることで瞳孔対光反射の分光感度に変化があったことが考えられ る. 分光感度が変化した放射量, 測光量を求める方法として, 457 $\mathrm{nm}$ 光と $539 \mathrm{~nm}$ 光による実験結果を近似した曲線の交点が利用さ れた. 水晶体の分光透過特性の加齢変化を考慮したことで, 交点の 放射量の個人差が小さくなった。このことから, 交点の放射量の值 は加齢によって変化すると考えられる. 近似曲線の交点前後の条件 数が被験者によって異なり，全体的に高放射量側の条件数が少なか った.このことから，より高い放射量の光条件を設定することがで きれば, 今回得られた値よりも交点の放射量の值は小さい值になっ たかもしれない.

今回, 2 種類の単色光から分光感度を推定した結果, 瞳孔対光反 射を調節する視物質のピーク波長は交点より暗い時には $510 \mathrm{~nm}$,

交点より明るい時には $479 \mathrm{~nm}$ にあることが示された。交点より暗 い時の $510 \mathrm{~nm}$ は既知の視物質の中では杆体のピーク波長が最も近 かった. 瞳孔対光反射は杆体の分光感度で調節されるといら既往報 告 7)があることから, 今回の実験結果は既往報告 7)に準じたものと 考えられる. 実験結果が杆体の視物質のピーク波長 $\left.(496 \mathrm{~nm}){ }^{12}\right)$ と一致しなかった理由としては, 暗順応時間が短かったことが考え
られる. 交点より明るい時の $479 \mathrm{~nm}$ は ipRGC の視物質のピー ク波長 $(479 \sim 484 \mathrm{~nm})$ 13) と一致した。 このことから, 交点より 明るい時の瞳孔対光反射の分光感度は ipRGC のみによって調節 されることが示唆される. 今回の分析によって, 高放射量曝露時 の瞳孔対光反射の分光感度に ipRGC の関与があるのか, あると したら錐体や杆体と協調しているのかという疑問に対する 1 つ の解を示すことができた．ただ， 2 種類の単色光を使った分析方 法は精度の点で不安があるため, より多くの単色光を使った分析 方法による検証が行われるべきだと考えられる.

ipRGC が関与寸る生物学的反応に関寸る研究では, 網膜疾患 のある動物を使ったり, 遺伝子操作や薬理学的な処理を施すこと

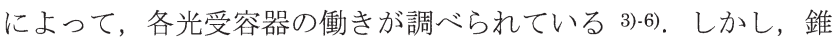
体や杆体から ipRGC にシナプス入力があり 14), その入力が ipRGC の光反応を抑制していることが示唆されている ${ }^{15)}$ ，そし て, ipRGC が関与する反応の 1 つである夜間の光曝露によるメ ラトニン分泌の抑制作用はその作用スペクトル 16)17)から複数の 光受容器が協調していることが示唆されている. 以上より, ipRGC が関与する生物学的反応は複数の光受容器が協調してい ることが示唆されており, 協調状態について理解するためには, 複数の光受容器が協調する状態で, その状態が推定できる実験を 寸る必要があると考えられる.

\section{5. まとめ}

2 種類の単色光を用いた実験から, 瞳孔対光反射の分光感度が 放射量に応じて変化することが分かった. 被験者 4 名の平均年齢 の水晶体をもつ被験者を仮定したところ, 29.3 scotopic lx 付近で 分光感度が変化することが示された. 高放射量曝露時の瞳孔対光 反射が ipRGC のみによって調節されることが示唆された。

\section{謝辞}

本報告は社団法人照明学会第 15 回（平成 18 年度）研究・教育 助成課題 (奨励研究: ipRGC が関与する生物学的反応に関する 研究）の助成によって行われました. また, 今回の研究を進める にあたり，実験方法および解析方法を改良するきっかけとなるコ メントを下さった関西大学の加藤未佳氏に感謝いたします.

\section{参考文献}

(1) D. M. Berson, F. A. Dunn and M. Takao : Phototransduction by retinal ganglion cells that set the circadian clock, Science, 295-5557, pp.1070-1073 (2002).

(2) S. Hattar, H.-W. Liao, M. Takao, D. M. Berson and K.-W. Yau : Melanopsin-containing retinal ganglion cells: Architecture, projections, and intrinsic photosensitivity, Science, 295-5557, pp.1065-1070 (2002).

(3) S. Panda, I. Provencio, D. C. Tu, S. S. Pires, M. D. Rollag, A. M. Castrucci, M. T. Pletcher, T. K. Sato, T. Wiltshire, M. Andahazy, S. A. Kay, R. N. Van Gelder and J. B. Hogenesch : Melanopsin is required for non-image-forming photic responses in blind mice, Science, 301-5632, pp.525-527 (2003).

(4) R. J. Lucas, S. Hattar, M. Takao, D. M. Berson, R. G. Foster and K.-W. Yau : Diminished pupillary light reflex at high irradiances in melanopsin-knockout mice, Science, 299-5604, pp.245-247 (2003).

(5) P. D. R. Gamlin, D. H. McDougal, J. Pokorny, V. C. Smith, 
K.-W. Yau and D. M. Dacey : Human and macaque pupil responses driven by melanopsin-containing retinal ganglion cells, Vision Res., 47-7, pp.946-954 (2007).

(6) F. H. Zaidi, J. T. Hull, S. N. Peirson, K. Wulff, D. Aeschbach, J. J. Gooley, G. C. Brainard, K. Gregory-Evans, J. F. Rizzo III, C. A. Czeisler, R. G. Foster, M. J. Moseley and S. W. Lockley : Short-wavelength light sensitivity of circadian, pupillary, and visual awareness in humans lacking an outer retina, Curr. Biol., 17-24, pp.2122-2128 (2007).

(7) I. H. Wagman and J. E. Gullberg: The relationship between monochromatic light and pupil diameter. The low intensity visibility curve as measured by pupillary measurements, Am. J. Physiol., 137-4, pp.769-778 (1942).

(8) T. D. Lamb : Photoreceptor spectral sensitivities: Common shape in the long-wavelength region, Vision Res., 35-22, pp.3083-3091 (1995).

(9) A. Stockman, L. T. Sharpe and C. Fach : The spectral sensitivity of the human short-wavelength sensitive cones derived from thresholds and color matches, Vision Res., 39-17, pp.2901-2927 (1999).

(10) J. Pokorny, V. C. Smith and M. Lutze : Aging of the human lens, Appl. Opt., 26-8, pp.1437-1440 (1987).

(11) D. M. Bronstein, G. H. Jacobs, K. A. Haak, J. Neitz and L. D. Lytle : Action spectrum of the retinal mechanism mediating nocturnal light-induced suppression of rat pineal gland N-acetyltransferase, Brain Res., 406-1-2, pp.352-356 (1987).

(12) H. J. A. Dartnall, J. K. Bowmaker and J. D. Mollon : Human visual pigments: microspectrophotometric results from the eyes of seven persons, Proc. R. Soc. Lond., B, Biol. Sci., 220-1218, pp.115-130 (1983).

(13) G. C. Brainard and J. P. Hanifin : Photons, clocks, and consciousness, J. Biol. Rhythms, 20-4, pp.314-325 (2005).

(14) D. M. Dacey, H.-W. Liao, B. B. Peterson, F. R. Robinson, V. C. Smith, J. Pokorny, K.-W. Yau and P. D. Gamlin : Melanopsin-expressing ganglion cells in primate retina signal colour and irradiance and project to the LGN, Nature, 433-7027, pp.749-754 (2005).

(15) F. A. Dunn and D. M. Berson : Are intrinsically photosensitive retinal ganglion cells influenced by rods or cones, Invest. Ophthalmol. Vis. Sci., 43, E-Abstract 2982 (2002).

(16) G. C. Brainard, J. P. Hanifin, J. M. Greeson, B. Byrne, G. Glickman, E. Gerner and M. D. Rollag : Action spectrum for melatonin regulation in humans: Evidence for a novel circadian photoreceptor, J. Neurosci., 21-16, pp.6405-6412 (2001).

(17) K. Thapan, J. Arendt and D. J. Skene : An action spectrum for melatonin suppression: Evidence for a novel non-rod, non-cone photoreceptor system in humans, J. Physiol., 535-1, pp.261-267 (2001).

（受付日 2010 年 4 月 26 日/採録日 2010 年 8 月 6 日）

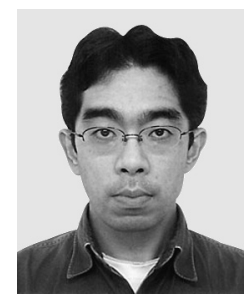

高橋 良香（正会員）

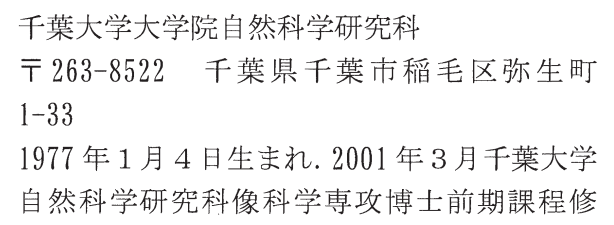
了. 2004 年 4 月千葉大学大学院自然科学研究科人間環境デザイン 科学専攻博士後期課程入学. 現在在学中. 日本視覚学会, 照明学 会, 日本色彩学会, 日本時間生物学会, 日本生理人類学会会員.

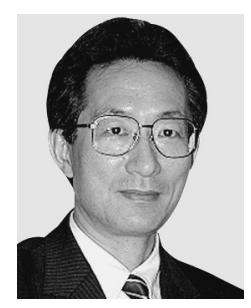

勝浦 哲夫（非会員）

千葉大学大学院工学研究科

干263-8522 千葉県千葉市稲毛区弥生町 $1-33$

1950 年 1 月 30 日生まれ. 1972 年 3 月九州芸 術工科大学芸術工学部工業設計学科卒. 1986 年京都大学理学博士. 1974 年九州芸術工大学芸術工学部助手, 1980 年千葉大学工学部講師, 1986 年同助教授を経て, 1996 年同 教授. 専門は生理人類学, 環境人間工学. 2007 年より日本生理人 類学会会長.

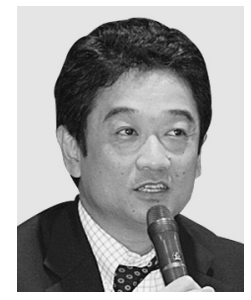

岩永 光一 (非会員)

千葉大学大学院工学研究科

干 263-8522 千葉県千葉市稲毛区弥生町 $1-33$

1958 年 8 月 5 日生まれ. 1981 年 3 月九州芸術 工科大学大学院芸術工学研究科修士課程修 了. 九州芸術工科大学助手, 千葉大学助教授等を経て, 現在千葉 大学教授. 博士 (理学). 日本生理人類学会等会員.

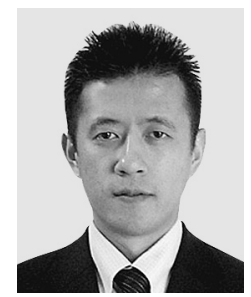

下村 義弘（非会員）

\section{千葉大学大学院工学研究科}

テ263-8522 千葉県千葉市稲毛区弥生町 1-33

1972 年 12 月 20 日生まれ. 2000 年 3 月千葉大 学大学院自然科学研究科修了, 同年 4 月千葉 大学大学院助手, 現在同大学准教授, 博士（工学）, 日本生理人 類学会理事, 日本人間工学会, 日本デザイン学会等会員. 